\title{
DOES NATIONAL CULTURE MATTER? AN EXPLORATORY STUDY ON THE RELATIONSHIP OF NATIONAL COMPETITIVENESS AND NATIONAL CULTURE
}

\author{
Sofik Handoyo ${ }^{*} 1$ \\ *) Faculty of Economic and Business, Universitas Padjadjaran \\ Jl. Dipati Ukur 35, Bandung, 40132
}

\begin{abstract}
The purpose of the study is to examine empirically the relationship between national competitiveness and national culture. The study applied exploratory research design with national culture and national competitiveness treated as two independent variables. Hofstede's national culture categorization namely masculinity, individualism, uncertainty avoidance, power distance, and long-term orientation was adopted. Cultural Index by GLOBE study and Global Competitiveness Index (GCI) by the World Economic Forum were used for the measurement. Descriptive statistic along with bivariate correlation analysis was used in this study. A number of samples involved in this study was 58 countries. The study concludes that national competitiveness is positively and significantly associated with national culture namely long-term orientation, uncertainty avoidance, and individualism. National competitiveness has a negative association with power distance national culture. However, national competitiveness was indicated no association with masculine national culture. The findings conclude that in general, national culture is a factor that explains why there are differences in national competitiveness among countries around the world. A suggestion for future similar research is that control variable such national income as well as the application of more sophisticated statistical analysis method should be included.
\end{abstract}

Keywords: exploratory study, global competitiveness index, national culture; national competitiveness; national culture index

\begin{abstract}
Abstrak: Tujuan dari penelitian adalah menguji secara empiris hubungan antara daya saing negara dengan budaya negara. Penelitian mengunakan pendekatan ekplorasi dengan variabel daya saing negara dan budaya negara diperlakukan sebagai dua variabel bebas. Penelitian mengadopsi model budaya negara dari Hofstede yang meliputi pengkategorian budaya kedalam masculinity, individualism, uncertainty avoidance, power distance dan long-term orientation. Pengukuran variabel budaya negara mengunakan indek budaya negara yang diterbitkan oleh GLOBE study. Indek daya saing global yang diterbitkan oleh World Economic Forum adalah proksi untuk pengukuran daya saing negara. Jumlah sampel penelitian yang dilibatkan adalah 58 negara. Hasil penelitian menunjukan bahwa daya saing suatu negara berhubungan postif dan signifikan terhadap kategori budaya negara long-term orientation, uncertainty avoidance, dan individualism. Sedangkan daya saya negara mempunyai hubungan negatif dengan kategori budaya negara power distance. Namun demikian, daya saing negara tidak mempunyai korelasi dengan budaya negara kategori masculine. Hasil penelitian secara umum dapat di simpulkan bahwa budaya negara adalah salah satu faktor yang menjelaskan adanya perbedaan daya saing negara-negara di dunia. Saran untuk penelitian sejenis di masa mendatang adalah memasukan variabel pengendali seperti halnya pendapatan nasional dan juga mengunakan model analisis statistik yang lebih komprehensif.
\end{abstract}

Kata kunci: budaya negara; daya saing negara; ekplorasi; indek budaya negara; indek daya saing global

${ }^{1}$ Corresponding author:

Email: sofik.handoyo@unpad.ac.id 


\section{INTRODUCTION}

International competitiveness is a key element for the country to achieve sustainable economic development (Apsalone and Sumilo, 2015). A tremendous concern of study has been addressed to understand the correlation among diversity of national cultural, value systems of the country and national competitiveness (Rosselet, 2014). National culture is a pivotal factor in determining national competitiveness (Bosch and Prooijen, 1992). Because of the increasing number of companies operating globally, it is important to understand the national culture of the country where the companies are established. National culture has been believed to have a pivotal role in international business, therefore, its attributes become a major interest of multinational firms to be understood (Michaela et al. 2011, Moon and Choi, 2001, Mac-Dermott, 2015). In order to obtain benefits of globalization, the multinational firms must consider how to deal with and utilize national culture as the power to maximize their business performance (Bayias and Assimakopoulos, 2011).

National culture is believed as a determinant that explains why a certain country is more developed than another even though located in the same region (Mihaela et al. 2011). Rosselet (2014) argues that the country's national heritage is a factor that can drive sustainable economic development. Tradition and value system are considered to have a positive influence on working ethics, and it can increase national competitiveness (Mihaela et al. (2011). National culture provides a country with its uniqueness value, and it can be used as an advantage opportunity to increase national competitiveness (Apsalone and Sumilo, 2015). The values derived from national culture will determine how individual in society behave both in private and governmental organizationa. National culture can be an impediment to national development if the society does not have values and beliefs that support the spirit of competitiveness (OECD, 2003).

There are various definitions and models of national model proposed by Geert Hofstede is the most frequently cited and recognized in the academic literature (Moon and Choi, 2001). Hofstede and Hofstede (2005) argue that each individual belongs to a group, and it will culture that have been defined and developed by respected international scholars. However, national culture be recognized as a symbol of identity. Geert Hofstede proposed national culture into five categories, namely,
Uncertainty Avoidance, Individualism vs Collectivism, Masculinity vs femininity, Power Distance, Longterm Orientation vs. Short-term Orientation. National culture index released by GLOBE study is an indicator to measure national culture, and lately it has gained its popularity due to its improvement of national culture measurement previously initiated by Hofstede (Globalproject, 2007).

National competitiveness is a fundamental aspect to survive in the globalization era. World Economic Forum (WEF) emphasizes national competitiveness definition as productivity of the country (Porter \& Schwab, 2008). OECD (2003) defines national competitiveness as the country's ability to produce goods and services that pass the international standard. Meanwhile, National Competitiveness Council views national competitiveness as the ability of the country to compete in an international market that leads to improvement of a country's standard of living (Ketels, 2016). International Institute for Management Development's (IMD) sees the prosperity of the country as an indicator to measure national competitiveness as a result of capability in managing total competencies.

Beliefs and values existing in a society are a key factor to define national culture. National culture becomes identity, norms, and codes of conduct of the society and a symbol of the character of the nation (Rosselet, 2014). Beliefs and value rooted from national culture act as unwritten rules and regulations to guide actions and behaviors of the society (Apsalone and Sumilo, 2015). A strong national culture that supports national competitiveness can be a social capital for the country. National culture is the identity of the country and represents the behavior of society in that country. National culture has the capacity to influence the individual in terms of the view of thinking and behavioral action (Moon and Choi, 2001). National culture is a fundamental aspect that makes countries have differences including their national competitiveness (House, 2004).

Impact of cultural differences on business organization has been studied by many scholars (Moon and Choi, 2001). In the marketing field of study, Steenkamp (2001) studied the role of national culture in international marketing and conducted a study on advertising sensitivity to the business cycle. Shore and Cross (2005) explored the role of national culture in international project management. Lewellyn and Bao (2017) studied 
national culture on earning management and corruption in firms in 26 countries. Chen et al. (2017) studied national culture and corporate innovation. However, attention to study the relationship of national culture on the country capability especially competitiveness is not sufficiently enough. It can be identified from limited literature reviews and empirical evidence available that discuss the role of national culture on the aspect of national level. Previous studies on the role of national culture in national level focused more on the governance perspective. Seleim and Bontis (2009) study the role of national culture on corruption on the national level.

Curiosity toward cultural involvement in national competitiveness is driven by the fact the countries located in the same geographical area showed differences in national competitiveness. In order to prove whether there is a cultural influence on national competitiveness or not, this study applies empirical analysis to understand that. Objects of the study are national culture and national competitiveness. Since relatively limited literature reviews related to the study are available, this study aims to understand the association between national culture and national competitiveness using an exploratory approach. The countries involved as the subject of the investigation are limited to those registered in cultural index released by GLOBE study. This study is expected to answer remaining curiosity about the role of national culture as an inherent factor that determines national competitiveness.

\section{METHODS}

Global Competitiveness Index (GCI) is an indicator to measure national competitiveness developed by World Economic Forum (WEF). The index is stated in an interval scale from 1 (Minimum) to 7 (Maximum). GCI is measured using many different components of national competitiveness pillars. These components are grouped into 12 interrelated pillars of national competitiveness. The pillars of national competitiveness in GCI consist of infrastructure, quality of institutions, health and primary education, labor market efficiency, higher education and training, technological readiness, financial market development, market size, business sophistication, innovation, goods market efficiency, and macroeconomic environment.
The variable national culture was measured using Cultural Index published by GLOBE study. Meanwhile, National competitiveness variable was measured using the Global Competitiveness Index (GCI) released by the World Economic Forum and both indexes have 7 point interval scale $(1=$ Minimum, $7=$ maximum $)$. The data were obtained directly from the open publication of official website of GLOBE study and World Economic Forum.

The population of this study was the countries listed officially in United of Nations. A total number of samples involved in this study were 58 countries. The time period of investigation was the year of 2016. Due to the consideration of the availability of specific data at the specific time period of investigation, purposive sampling technique was adopted. The study used secondary data collected through official website of World Economic Forum and GLOBE study. The study applied exploratory research approach because the research was categorized as a preliminary research. The descriptive statistical analysis was used to give a basic explanation of the data analyzed. In order to get justification proposed hypotheses, Pearson Bivariate Correlation was applied in this study.

Individualistic society is a society that believes that each individual is responsible for themselves and they do not need to be emotionally dependent on other individuals or groups (Davis and Ruhe, 2003). Focusing on individual achievement is a characteristic of a society with high individualism. They judge an individual based on skill and achievement, not by gender, seniority or social status. Individualistic society adheres to equality, avoids discrimination based on hierarchy, and respects for individual achievement (Moon and Choi, 2001). Collectivist societies are identified as a society with high social bonding, emotional dependence on the group and rely on group decisions (Davis and Ruhe, 2003). Individual who lives in a collective society can only accept criticism sourced from the group. Collective society considers values that implies rules and regulation as a representation of the group. Each group has different values and beliefs; therefore, applying different standards is the best option when evaluating different group. Research finding from the previous study leads to the conclusion that high score of individualism national culture is closely associated with the competitive country (Mihaela et al. 2011). It is because a society with 
individualistic national culture puts high appreciation on the performance of the individual. If the standard of achievement is individual performance; therefore, in accumulation it will be reflected on the national level. Therefore, the hypothesis is proposed as follows: Hypothesis 1: National competitiveness is associated with individualism national culture, so the more masculine the national culture, the more competitive the nation.

High power distance national culture is the culture with a characteristic such as the existence of inequality, dependency on a leader, and hierarchical social structure. A society with high power distance acknowledges the leader as a legitimate power; therefore, they would respect higher level hierarchy. Meanwhile, low power distance society, superiors, and subordinates show narrow gap personal relationship; thus, it results in a harmony and cooperative environment. Titles, status, and formality command are less important in low power distance society (Davis and Ruhe, 2003). Individuals who live in countries with low power distance category are familiar with the empowerment of low-level hierarchy, cross-functional organization and simple structure organization (Wursten and Jacobs, 2014). High power distance culture tends to have a society that obeys the order from higher level hierarchy with no demand for further justification (Hofstede, 2001) Elite's individual is a representation of total population and leaving important decisions to be made by the high-level hierarchy. Inequality in high power distance culture is a reflection of authority as a central value (Tabellini, 2009). An individual who lies in the low-level hierarchy of society rarely has a chance to express ideas and suggestion. Williamson and Mathers (2010) suggest that society with a high degree of obedience on the higher level hierarchy is not supporting national competitiveness due to lack of empowerment. Therefore, the hypothesis is proposed as follows: Hypothesis 2: National competitiveness is associated with low power distance national culture, so the lower power distance national culture, the more competitive the nation.

A society with uncertainty avoidance national culture is a society with a characteristic that prefers to avoid ambiguous situations and more comfortable with certainty and predictability environment (Davis and Ruhe, 2003). An individual with high uncertainty culture avoidance seems to avoid risk and individuals who live in low uncertainty avoidance are identified as risk takers (Hofstede, 2001; Kovačić, 2005). A society with uncertainty culture prefers to avoid ambiguous circumstances, especially for business organizations (Bosch and Prooijen, 1992). Firms whose business operation located in countries and are identified as high-level uncertainty avoidance culture prefer to use legal contracts as the basis for a business relationship. Calculating risk and being resistant to change are two common characters found in high uncertainty avoidance culture. A society with low uncertainty avoidance national culture is relatively open to new ideas and beliefs. On the other hand, a society with high uncertainty avoidance culture is relatively protective and prudent toward influences from outside and have less willingness to leave their own safe environment. A society with strong uncertainty avoidance prefers the relationship with the predicted outcome; therefore, they are very prudent in making a decision. Bosch and Prooijen (1992) argue that a society with low-level uncertainty avoidance, tends to be more open toward a relationship with others. However, a society with high uncertainty avoidance use calculation risk and benefit to deal with a business partner; therefore, potential risks that will be faced in the future can be managed. Based on the explanation above, the hypothesis can be proposed as follows: Hypothesis 3: National competitiveness is associated with lower uncertainty avoidance national culture, so the lower uncertainty avoidance national culture level, the more competitive the nation.

A society with a masculine culture is identified to have a characteristic such as assertiveness, materialism, selfishness. People who live in masculine culture have higher concerns with an opportunity for high earning, recognition for a job achievement, promotion, and challenges, competitiveness, success, status, wealth, material success, ambition, and achievement (Moon and Choi, 2001, Wursten and Jacobs, 2014). A society with masculine culture tends to have perfectionism orientation in terms of performing their job or duties (Wursten and Jacobs, 2014). Bosch and Prooijen (1992) argue that a masculine society has values such as the spirit of struggling and competing. A society with feminism national culture considers that individual relationships, empathy, and quality of life are important (Adler, 2002). They tend to put social needs as a priority over the productivity (Adler, 2002). People living in feminism national culture find that job satisfaction and flexibility are more important than the achievement 
of challenging job or duties (Miroshnik, 2002). A feminine society does not have much target orientation, enjoys life with flows and has a jargon such as small is beautiful and better late than never (Hofstede, 1997). Therefore, the hypothesis can be formulated as follows: Hypothesis 4: National competitiveness is associated with masculine national culture, the more masculine national culture level, the more competitive the nation.

A society with national culture which is identified as Long-term orientation has the character identity of perseverance and thrift. Perseverance is an individual character with a characteristic such as determination and consistency effort to achieve goals. The visionary individual is a representation of society that lives in the long-term orientation of national culture. Meanwhile, the life of a society with a short-term orientation culture and having no a long-term objective relatively flows smoothly and lacks of pressure. People who live in short-term national culture tend to be grateful and have no high ambition involved. Research finding indicates that managers who run the companies located in a country with high long-term orientation culture tend to have a strong orientation on building a market position (Deleersnyder et al. 2009). A society with long-term orientation cultures concerns about future orientation and have ambition in achieving economic success. Mac-Dermott and Mornah (2015) argue that in an Interorganizational relationship, economic opportunity and expectation of long-term sustainability relationship are the two fundamental aspects that determine motivation. Therefore, the hypothesis can be formulated as follows: Hypothesis 5: National competitiveness is associated with long-term orientation national culture, so the more long-term orientation national culture level, the more competitive the nation

Each country has a stronger culture with very intense accents either of individualism or collectivism, big or small power distance, uncertainty control and masculinity or femininity (Mihaela et al. 2011). Strong culture of the country will be a social capital for the country to improve national competitiveness. Porter's diamond theory (1990) explained that MNEs' international success was a result of the competitive advantages embedded in their home bases, and it refers to national culture. National culture differences across countries are believed to be the fundamental factor that makes one country more advanced compared to other countries. National culture is a system (believe) that is reflected in the individual attitude and becomes a character of the society. Positive attitude and character of the individual in a certain society in a certain country will be a valuable capital for the country in the development and improvement of its national competitiveness. The framework of this research is presented in Figure 1.

\section{RESULTS}

\section{Descriptive Statistics}

In this study, national culture referring to the definition of national culture was developed by Hofstede. It refers to five classifications of national culture terminology, namely, uncertainty avoidance, short-term/long-term orientation, power distance, individualism/collectivism, masculinity/femininity, and national competitiveness. The total of the countries involved in this study was 58 countries and the descriptive statistic of national culture score is presented in Table 1. The descriptive statistic analysis was intended to get a basic understanding on the five national cultures of the samples involved in this study. Information presented in Table 1 indicates that national culture consisting of power distance, shortterm/long-term orientation, uncertainty avoidance, individualism/collectivism, and masculinity/ femininity was at a relatively moderate value (mean value lies between 3.39 and 5.14). It implies that the level of national culture of the samples is relatively homogeneous. It also indicates that the countries that have been categorized into certain national culture categorization have no significant differences in their national culture score.

Value of coefficient variation of national culture indicates that the data used in the study were normally distributed (Coefficient Variation Value $<30 \%$ ). Low coefficient variation $(<30 \%)$ means that the gap between the highest score and lowest score of each categorization of national culture is relatively narrow. It means that there is no outlier of the data processed in this study (an extreme low and an extreme high of national culture score). It also gives us understanding that based on Hofstede national culture model, there is no superiority or inferiority of national culture score for each categorization. In each categorization of national culture, it tends to have a moderate value of national culture. Based on the basis descriptive statistics as a 
justification of variation of national culture, it can be concluded that countries around the world may be from one culture originated back many previous years. Geographic separation along with the development of civilization may affect each country so that it will have a different characteristic in its national culture. However, the hypotheses need to be proven empirically and further studies involving more countries around the world are necessary.

Regarding the national competitiveness score adapted from the Global Competitiveness Index (GCI) by the World Economic Forum (WEF), national competitiveness index of the countries involved in this study is on the moderate level. Information, as stated in Table 1, indicates that the mean value of national competitiveness index of 58 countries is 4.55 . With the consideration that minimum value is 1 and the maximum value is 7 , it can be justified that national competitiveness index of countries involved in this study is on a moderate level. GCI has the coefficient of variation value of $15 \%(<30 \%)$, and it justifies that the samples have no indication of significant differences in the level of national competitiveness index. Furthermore, the results of the coefficient of variation value indicate that the data used in the study were normally distributed. Statistically, there is no indication that the samples have a tendency to have an extreme value of national competitiveness (extreme worst or extreme best).

Descriptive statistic of national competitiveness score as depicted in Table 1 justifies that national competitiveness of the countries involved in this study is on a moderate level. However, it is a fact that a number of developed countries are far less than developing and under-developed countries. The average value of national competitiveness score may not represent all of the population countries in the world. Furthermore, there is a certain condition that the economic gap between developed countries with developing and underdeveloped countries is very wide. Therefore, if all of the countries in the world are involved, the average value of national competitiveness score has a high possibility to be below the moderate value $(<4.55)$ and coefficient of variation value is higher than $30 \%$. Therefore, to understand the relationship of national culture and national competitiveness comprehensively, future studies must consider the representation of countries based on their economic classification (developed countries, developing countries and under developing countries).

Phenomenon:

The differences of National Competitiveness level among countries located in the same region

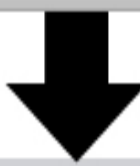

Variables Observed ( Hofstede National Culture Model)

Individualism National Culuture Power Distance National Culture Uncertainty Avoidance National Culture

Masculine National Culture Longterm Orientation National Culture
Conceptual Framework

( Mihaela et al. 2011 \& Porter, 1990)

The culture is, in most of the cases, the main explanation of the

fact that one country

is developed quicker

than other. competitive advantages embedded in their homebases
Variable Observed (World Economic Forum - Global Competitiveness Index)

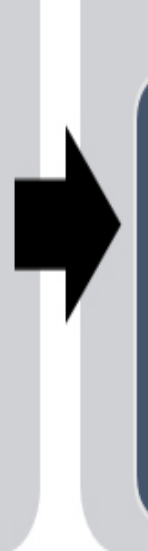

National Competitivenes

Figure 1. Research framework 


\section{Correlation Analysis}

This study has an objective to examine the relationship or association between two independent variables i.e. national culture and national competitiveness. The focus of this study is not to examine the influence of one variable on another variable, but the relationship between variables. In order to understand the relationship between national competitiveness and national cultures, this study applied correlation analysis procedure. Pearson Correlation Product Moment was applied because the data were a combination of ratio scale and interval scale. Correlation analysis is a statistical procedure intended to understand the relationship between two independent variables. The results of the Pearson correlation Product Moment between national cultures and national competitiveness are presented in Table 2.

The results presented in Table 2 indicate that the countries that fall into the category of uncertainty avoidance tend to have a long-term orientation national culture $(\mathrm{r}=0.768, \mathrm{p}<0.01)$, low power distance $(\mathrm{r}=-507$, $\mathrm{p}<0.01)$ and individualism national culture $(\mathrm{r}=0.451$, $\mathrm{p}<0.01$ ). Meanwhile, the countries with long-term orientation national culture tend to have a characteristic as low power distance national culture $(r=-0.441$, $\mathrm{p}<0.01)$ and individualism national culture $(\mathrm{r}=0.476$, $\mathrm{p}<0.01)$. The countries with high power distance tend to have collectivism national culture $(r=-0.279, \mathrm{p}<0.01)$ and masculinity national culture $(\mathrm{r}=-0.310, \mathrm{p}<0.01)$. The correlation analysis based on the correlation analysis in Table 2 may not represent the population of the countries in the world. This study only involved 58 countries or only $30 \%$ of the total countries registered as a member of the United Nations. Since Hofstede national culture score only limited to 58 countries and collected in early 1990, there is a concern in the future to conduct a recent study on national culture assessment and involve more countries. By using the recent surveys of national culture and involving more countries in the world, it is expected the results of the study become a reflection of current condition and representation of the total population of the countries registered in United Nations today.

Table 1. Descriptive statistics

\begin{tabular}{lcccccc}
\hline \multicolumn{1}{c}{ Variables } & $\mathrm{N}$ & Minimum & Maximum & Mean & Std. Deviation & Coefficient of Variation \\
\hline Uncertainty Avoidance & 58 & 2.88 & 5.37 & 4.15 & 0.59 & 0.14 \\
Short-term/ Long-term/ Orientation & 58 & 2.88 & 5.07 & 3.83 & 0.47 & 0.12 \\
Power Distance & 58 & 3.59 & 5.80 & 5.14 & 0.46 & 0.09 \\
Individualism/Collectivism & 58 & 3.25 & 5.22 & 4.25 & 0.43 & 0.10 \\
Masculinity/Femininity & 58 & 2.50 & 4.08 & 3.39 & 0.38 & 0.11 \\
National competitiveness & 58 & 2.88 & 5.67 & 4.55 & 0.70 & 0.15 \\
\hline
\end{tabular}

Table 2. Correlation Matrix

\begin{tabular}{lcccccc}
\hline Variables & 1 & 2 & 3 & 4 & 5 & 6 \\
\hline Uncertainty Avoidance & 1 & & & & & \\
Long-term orientation & $0.768^{* *}$ & 1 & & & & \\
Power Distance & $-0.507^{* *}$ & $-0.441^{* *}$ & 1 & & & \\
Individualism/Collectivism & $0.451^{* *}$ & $0.476^{* *}$ & $-0.279^{*}$ & 1 & & \\
Femininity/masculinity & -0.049 & -0.066 & $-0.310^{* *}$ & -0.074 & 1 & \\
National Competitiveness & $0.618^{* *}$ & $0.585^{* *}$ & $-0.389^{* *}$ & $0.410^{* *}$ & 0.021 & 1 \\
\hline
\end{tabular}

**)Correlation is significant at the 0.01 level (1-tailed); *) Correlation is significant at the 0.05 level (1-tailed). 
Based on information presented in Table 2, it implies that the countries that have prudent behavior and riskaverse ( uncertainty avoidance) tend to have long-term relationship orientation, equality of hierarchical of social status (low power distance) and strategic orientation with other countries. Additionally, the countries that have uncertainty avoidance national culture are more individualistic in a social relationship. The majority of the developed countries have a characteristic of uncertainty avoidance and tend to have long-term orientation, low power distance, and individualism. It implies that even though the survey of national culture conducted by Hofstede is already out of date (early 1990), if it is associated with the current situation, it is still relevant in certain aspects. The correlation analysis also shows that the countries that are categorized as having power distance national culture tend to have a character as a collective country $(\mathrm{r}=0.279, \mathrm{p}<0.05)$ and feminine country $(r=0.310, p<0.01)$. It implies that the countries that apply hierarchical in their structural life tend to live in togetherness (collective) and comfort with peacefulness environment (Feminism). Indonesia is one example of the country with a high power distance national culture and a collective society. Moreover, to some point, it has an orientation on society with peacefulness.

The correlation analysis results revealed that national culture based on the classification of Hofstede may fall into two categorization clusters associated with its national competitiveness. The first cluster is a categorization of national culture that supports national competitiveness, and in the second cluster, it is a categorization that is not supported with national competitiveness. The first cluster refers to national culture categorization of uncertainty avoidance national culture, long-term orientation national culture, low power distance national culture, individualism national culture and masculinity national culture. Meanwhile, the second cluster refers to short-term orientation national culture, high power distance national culture, collectivism national culture, femininity national culture. In order to obtain a detailed understanding of the validity of the clustering of national culture, correlation analysis between each categorization of national culture is required. The degree of correlation will determine whether there is an association between national culture and national competitiveness. Detail analysis of the relationship of national culture with national competitiveness is presented in the hypothesis testing section.

\section{Hypothesis Testing}

There are five hypotheses proposed in this research. The first hypothesis proposed that national competitiveness is positively and significantly associated with individualism in the national culture. Analysis correlation result concludes that the hypothesis is supported. It is indicated by Pearson Correlation Moment value ${ }^{\circledR}=0.410$ and $p<0.01$. The second hypothesis proposed that national competitiveness is negatively and significantly associated with power distance national culture. Statistical correlation result indicates Pearson Correlation Moment $(r)=-0.389$ at $\mathrm{p}<0.01$. It means that the second hypothesis proposed is supported. The third hypothesis proposed that national competitiveness is positively and significantly associated with uncertainty avoidance the national culture. Statistical correlation proved that the hypothesis is supported $(\mathrm{r}=0.618, \mathrm{p}<0.01)$. The fourth hypothesis proposed that national competitiveness is positively and significantly associated with masculinity. The hypothesis, however, is not supported even though it indicates slightly positive correlation $(\mathrm{r}=0.021)$ but no significant indication. The fifth hypothesis proposed that national competitiveness is positively and significantly associated with the Long-term orientation of national culture. Pearson correlation analysis result proved that the fifth hypothesis is supported $(\mathrm{r}=0.585, \mathrm{p}<0.01)$. The summary of the hypotheses proposed and their conclusion is presented in Table 3 .

Based on the information stated in Table 3, it implies that all of the hypotheses proposed are supported except for hypothesis 4 . Referring to the correlation results between national culture and national competitiveness, it can be concluded that national culture, in general, does have a correlation with national competitiveness. The countries that have uncertainty avoidance national culture and long-term orientation national culture have a strong association $(r>0,5)$ with national competitiveness. Meanwhile, the countries that have individualism national culture and low power distance national culture have moderate $(r>5)$ correlation. A typical national culture based on the categorization of masculinity and femininity do not have a correlation with national competitiveness. The results give us the understanding that national competitiveness is not only about capital, natural resources, technology, and other physical things but also determined by the character of the society of the country. In some cases, the character of the society may be more important than physical 
resources. The experience of Japan after World War II is an example of how the character of society pays a high contribution to the creation of national competitiveness.

National culture is something inherent as the character of the country since the society existed. It is, therefore, national culture cannot be created or copy it and implemented in certain society instantly. It seems that the country that has unfavorable national culture may have a barrier to be a competitive country. However, we can learn from developed countries regarding their national culture. The positive value of national culture from a developed country that supports the process of transforming toward a competitive nation should be adopted. Through early education, the positive value of developed countries must be initiated. Even though it will take a long time, the transformation of national culture from early education is the natural and permanent way to change toward a national culture that supports process toward the competitive nation. The process of adoption positive value from developed countries in order to get the positive impact of it is relevant with the institutional theory which describes that something is being part of the organization or institutionalized through coercive isomorphism (forcing), mimetic isomorphism (imitate) and normative isomorphism (suggestion). Using perspective institutional theory, the country that has weak national competitiveness can imitate the character of the society of developed countries and implement through early education. By having a young generation with the same character with people who live in the developed country, the transformation being a competitive nation is wide open.

\section{Managerial Implication}

On the side of the business organization, the result of the study may help to provide valuable information for fund managers in determining best location related overseas expansion. Fund managers have traditionally been reluctant to invest in markets far away both geographically and culturally from their home markets (Griffin et al. 2017). To avoid wrong decision-related location of investment, fund managers can utilize relevant information such as from empirical research findings. Referring to the findings of the study, the countries that have strong national culture such as individualism, uncertainty avoidance, and long-term orientation are the best option as a destination for investment. Those countries will have a high probability of benefiting the business organization because of having a strong national culture that supports business organization competitiveness. There are studies indicating that countries with low power distance tend to have stronger innovation capabilities, which might impact a company's thinking about alternative locations for work requiring high levels of innovation (Ghemawat and Reiche, 2011; Sun, 2009).

Table 3. Summary of hypothesis testing

\begin{tabular}{|c|c|c|}
\hline Hypotheses & $\begin{array}{c}\text { Pearson } \\
\text { Correlation }\end{array}$ & Conclusion \\
\hline $\begin{array}{l}\text { H1: National competitiveness is positively and significantly associated with } \\
\text { Individualism national culture }\end{array}$ & $0.410^{* *}$ & Supported \\
\hline $\begin{array}{l}\text { H2: National competitiveness is negatively and significantly associated with Power } \\
\text { distance national culture }\end{array}$ & $-0.389 * *$ & Supported \\
\hline $\begin{array}{l}\text { H3: National competitiveness is positively and significantly associated with } \\
\text { Uncertainty avoidance national culture }\end{array}$ & $0.618 * *$ & Supported \\
\hline $\begin{array}{l}\text { H4: National competitiveness is positively and significantly associated with Masculine } \\
\text { national culture }\end{array}$ & 0.021 & Not Significant \\
\hline $\begin{array}{l}\text { H5: National competitiveness is positively and significantly associated with Long- } \\
\text { term Orientation national culture }\end{array}$ & $0.585^{* *}$ & Supported \\
\hline
\end{tabular}

**) Correlation is significant at the 0.01 level (1-tailed). 
Understanding national culture and national competitiveness may also help business managers of the companies located in the country that have low national competitiveness related benchmarking decision (Noort et al. 2016). Hiring for adaptability and investing in cross-cultural training can improve workforce capability and flexibility (Ghemawat and Reiche, 2011). It is also relevant for business managers to understand the culture of other countries for the purpose of market penetration (Craig and Douglas, 2006). In order to understand acceptable product or services in the overseas market, the business managers have a responsibility to understand the national culture of the target market. Marketing and organization are areas where human culture is of particular importance in the sense that marketing requires a deep understanding of customers (Ghemawat and Reiche, 2011)). It is, therefore, especially for multinational companies, the existence of cross-cultural management is very important (Testa, 2009). Firms that manage adaptation effectively are able to achieve congruence in various cultures where they operate while extending their main sources of advantage across borders, and in some cases even making cultural diversity itself is a source of advantage (Ghemawat and Reiche, 2011). By understanding the national culture of the target market, the companies are expected to provide the products that fit with market expectation.

To achieve project goals and avoid cultural misunderstandings, project managers should be culturally sensitive and promote creativity and motivation through flexible leadership (Anbari et al. 2003). National culture has also been shown to have an impact on manufacturing and supply chain practices, which can be useful for business managers to consider in a variety of contexts; analyzing manufacturing footprints, managing multi-plant operations, assessing competitors and suppliers and different countries (Ghemawat and Reiche, 2011). Effective use of crosscultural teams can provide a source of experience and innovative thinking to enhance the competitive position of organizations (Anbari et al. 2000). The business manager should initiate to improve the alignment or congruence between management practices and cultural contexts yields tangible business benefits (Ghemawat and Reiche, 2011). Emphasizing individual contributions can improve organization performance in more individualistic cultures and weak performance in more collectivistic cultures. Managers who wish to achieve significant changes in high power distance cultures are advised to put senior staff front and center in communication efforts, use legitimate authority, and "tell subordinates what to do (Ghemawat and Reiche, 2011). In contrast, in lower power distance cultures, it is more important to explain the reasons for the change, "allow for questions and challenges" and involve employees in figuring out how to implement the desired change (Bing, 2004)

\section{CONCLUSIONS AND RECOMMENDATIONS}

\section{Conclusions}

The study was designed to reveal the relationship between national competitiveness and national culture namely individualism, power distance, uncertainty avoidance, masculinity, and long-term orientation. All hypotheses proposed were supported except for the fourth hypothesis which refers to the association between national competitiveness masculinity national cultures with. The results are already in line with theory and literature used in this study. However, the fourth hypothesis comes with an unexpected result and contradictive with theory and literature. The countries that have national culture individualism, uncertainty avoidance, and long-term orientation have a potential benefit in terms of capability to compete with other countries in international level. The findings give us understanding that national competitiveness is not only about factors such as technological capability, economic power or natural resources. A national culture which is social value rooted and inherent in the society of the country may also have a contribution to determine national competitiveness.

National culture is inherent in the social value of the country; therefore, it cannot be duplicated by competitors. Benefits obtained from the power of national culture will be long-lasting. It is because of national culture is hard to vanish from the society. The countries that have national culture individualism, uncertainty avoidance, and long-term orientation are privileged countries. They can empower values rooted from the national culture in order to get a better position in terms of its competitiveness capability. Referring to the result of the research, it implies that national culture will determine competitiveness power or capabilities of the country. For the countries that have no national culture that is associated with national competitiveness may use policy cultural adoption such 
as through education abroad. It is expected that if more and more human resources obtain experiences from countries that have a national culture that supports national competitiveness, they can transform it in their home country. Results of this study are confirmatory that the resources that support national competitiveness are not only natural resources, financial capital, and technology, but also cultural capital.

\section{Recommendations}

In order to obtain a generalization of conclusion, a suggestion for future research is to extend the time period of investigations and add more samples involved in the study. Furthermore, qualitative analysis using case study is encouraged to be conducted for the purpose of understanding in more detail the association between national culture and national competitiveness. Specifically, understanding the influence of the aspect of national culture in a governmental institution or in a private sector organization. This study was conducted using an exploratory research approach focusing on the analysis of two independent variables. Therefore, for future research, causal research approach using multiple regression analysis is strongly recommended. Adding a control variable such as income categorization is also strongly recommended for future similar research.

On the aspect of further understanding about the national culture, assessing national culture in current context is relevant. It is to answer the question of whether national culture is changing over time or not. Hosftede national culture score is out of date if we look at the first time national culture assessed (early 1990). Therefore, there is an urgency to obtain the current status of national culture based on the recent study. Furthermore, these research findings should be confirmed with another model of national culture and another instrument of national competitiveness instrument.

\section{REFERENCES}

Apsalone M, Šumilo E. 2015. Socio-cultural factors and international competitiveness. Business, Management, and Education 13(2): 276-291. https://doi.10.3846/bme.2015.302.

Adler N. 2002. International Dimensions of Organizational Behavior (4th ed.). SouthWestern, Cincinnati, OH.

Anbari FT, Khilkhanova EV, Romanova MV, Umpleby
SA. 2003. Cross-Cultural Differences And Their Implications For Managing International Projects.https://www2.gwu.edu/ umpleby/ recent_papers/2003_cross_cultural_ differences_managin_international_projects_ anbari_khilkhanova_romanova_umpleby.htm

Bayias P, Assimakopoulos V. 2011. The significance of national culture differences for domestic companies that expand to the international environment. International Journal of Business and Management Studies 3(2):237-247.

Bosch FAJ, Van D, Prooijen AAV. 1992. An emerging competitive advantage of European Nation. European Management Journal 10(4): 445448.

Bing JW. 2004. Hofstede's consequences: The impact of his work on consulting and business practices. Academy of Management Perspectives 18(1). https://doi.org/10.5465/ame.2004.12689609.

Chen Y, Podolski EJ, Veeraraghavan M. 2017. National culture and corporate innovation. PacificBasin Finance Journal 43:173-187. https://doi. org/10.1016/j.pacfin.2017.04.006.

Craig CS, Douglas SP. 2006. Beyond national culture: implications of cultural dynamics for consumer research. International Marketing Review, 23(3):322-342.

Deleersnyder B, Dekimpe MG, Steenkamp, JanBenedictEM, Leeflang. 2009. The role of national culture in advertising's sensitivity to business cycles: an investigation across continents. Journal of Marketing Research 46(5):623-636. https://doi.org/10.1509/jmkr.46.5.623

Davis JH, Ruhe JA. 2003. Perceptions of country corruption: antecedents and outcomes. Journal of Business Ethics 43(4): 275-288.

Ghemawa P, Reiche S. 2011. National Cultural Differences and Multinational Business. Globalization Note Series, GLOBE course at IESE Business School.

Globalproject. 2007. An overview of the 2004 study: Understanding the RelationshipBetween National Culture, Societal Effectiveness and Desirable Leadership Attributes. http:/globeproject.com/ study_2004_2007 [22 December 2017].

Griffin DW, Guedhami O, Kwok CCY, Li K, Shao L. 2017. National culture and the value implication of corporate governance. SSRN: https://ssrn. com/abstract $=2400078$ [22 December 2017].

House RJ, Hanges PJ, Javidan M, Dorfman PW, Gupta V.2004. Culture, Leadership, and Organizations: 
The GLOBE Study of 62 Societies. Sage Publications, Thousand Oaks.

Hofstede G, Hofstede GJ. 2005. Cultures and Organizations. Software for the Mind. 2nd ed. New York: McGraw-Hill.

Kovačić ZJ. 2005. The impact of national culture on worldwide eGovernment readiness. Informing Science Journal 8:143-158.

Ketels C. 2016. An Analysis Conducted for the Irish National Competitiveness Council. National Competitiveness Council, Dublin, March.

Lewellyn KB, Bao SR. 2017. The role of national culture and corruption on managing earnings around the world. Journal of World Business. 52(6): 798808. https://doi.org/10.1016/j.jwb.2017.07.002.

Mac-Dermott R, Mornah D. 2015. The Role of Culture in Foreign Direct Investment and Trade: Expectations from the GLOBE Dimensions of Culture. Open Journal of Business and Management 3:63-74.

Miroshnik V. 2002. Culture and international management: a review. Journal of Management Development 21(7): 521-544. https://doi. org/10.1108/02621710210434647.

Moon H, Choi E. 2011. Cultural impact on national competitiveness. Journal of International and Area Studies 8(2):21-36.

Mihaela H, Claudia O, Lucian B. 2011. Culture and national competitiveness. African Journal of Business Management 5(8):3056-3062.

Mathers RL, Williamson CR. 2011. Cultural context: explaining the productivity of capitalism. Kyklos 64(2):231-252. https://doi.org/10.1111/j.14676435.2011.00504.x.

Noort C, Reader TW, Shorrock S, Kirwan B. 2016. The relationship between national culture and safety culture: implications for international safety culture assessments. Journal of Occupational and Organizational Psychology 89(3): 515-538. https://doi.org/10.1111/joop.12139.

OECD. 2003. Challenges/Obstacles Faced by Competition Authorities in Achieving Greater Economic Development through the Promotion of Competition. Paris: OECD.
PorterME,SchwabK.2008. The Global Competitiveness Report 2008-2009. World Economic Forum Geneva, Switzerland.

Porter ME. 1990. The competitive advantage of nations. Harvard Business Review. March-April 1990 Issue. https://doi.org/10.1007/978-1-34911336-1.

Rosselet S. 2014. Can a Nation's Culture drive Competitiveness?.http://www.globaltrends. com/2014/12/01/can-a-nation-s-culture-drivecompetitiveness/

Shore B, Cross BJ. 2005. Exploring the role of national culture in the management of large-scale international science projects. International Journal of Project Management 23(1):55-64. https://doi.org/10.1016/j.ijproman.2004.05.009.

Steenkamp J, Benedict EM. 2001. The role of national culture in international marketing research. International Marketing Review 18(1): 30-44. https://doi.org/10.1108/02651330110381970.

Sun H. 2009. A meta-analysis on the influence of national culture on innovation capability. International Journal of Entrepreneurship and Innovation Management 10(3-4): 353-360. https://doi.org/10.1504/IJEIM.2009.025678.

Seleim A, Bontis N. 2009. The relationship between culture and corruption: a cross-national study, Journal of Intellectual Capital 10(1): 165-184. https://doi.org/10.1108/14691930910922978.

Tabellini G. 2010. Culture and Institutions, Economic Development in the Regions of Europe. Journal of the European Economic Association 8(4): 677716. https://doi.org/10.1111/j.1542-4774.2010. tb00537.x.

Testa MR. 2009. National culture, leadership, and citizenship: Implications for cross-cultural management. International Journal of Hospitality Management 28(1): 78-85. https:// doi.org/10.1016/j.ijhm.2008.04.002.

Wursten H, Jacobs C. 2014. The impact of culture on education: Can we introduce best practices in education across countries? Club of Amsterdam Journal :1-24. 